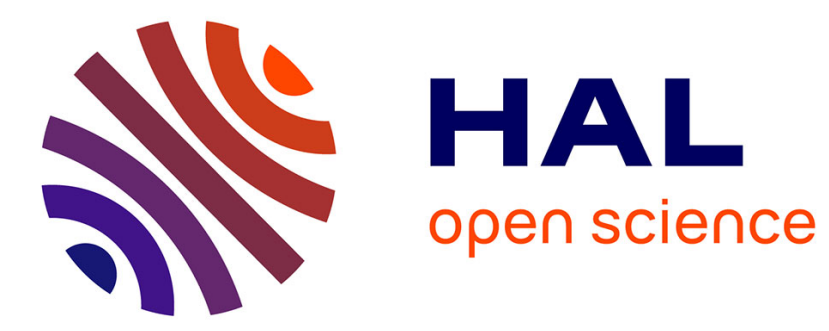

\title{
The laborious structuring of traumatology in France
} Thierry Bege

\section{To cite this version:}

Thierry Bege. The laborious structuring of traumatology in France. Journal of Visceral Surgery, 2019, 156 (1), pp1-2. 10.1016/j.jviscsurg.2018.12.004 . hal-03251931

\section{HAL Id: hal-03251931 https://hal.science/hal-03251931}

Submitted on 7 Jun 2021

HAL is a multi-disciplinary open access archive for the deposit and dissemination of scientific research documents, whether they are published or not. The documents may come from teaching and research institutions in France or abroad, or from public or private research centers.
L'archive ouverte pluridisciplinaire HAL, est destinée au dépôt et à la diffusion de documents scientifiques de niveau recherche, publiés ou non, émanant des établissements d'enseignement et de recherche français ou étrangers, des laboratoires publics ou privés. 


\section{The laborious structuring of traumatology in France}

\section{Author: Thierry Bège}

Any surgeon on call is familiar with the acute tension that appears on the arrival of a patient presenting with unstable abdominal trauma. The atmosphere has to do not only with the life-threatening nature of the injury, but also with an urgent need to decide rapidly and collegially on decisive action, as well as possible surgical hemostasis in a hostile context of massive hemoperitoneum. While these extreme emergency situations galvanize medical residents, they are often dreaded by young surgeons, who are lacking in training and practice. Traumatology activities have recently undergone considerable change, and the four articles published in this issue of the Journal of Visceral Surgery ${ }^{1-4}$ shed light on ongoing and upcoming evolution.

First and foremost, traumas themselves have changed. The terrorist attacks in France over recent years have led to redefinition of training priorities. All surgeons involved in first-line treatment of trauma from a gunshot wound are concerned and need to be fully prepared, given that the attacks have taken place not only in large urban centers (Nice, Paris, Marseille), but also in small towns and villages (Trèbes, Saint-Etienne-du-Rouvray). Medical response to these attacks demands specific organization in the framework of dedicated action plans (plans blancs). Surgeons are called upon to fulfill a key role in their design and implementation, and also to actively participate in simulation exercises. The experience of the Nice attacks described by Dr Damien Massalou ${ }^{1}$ illustrates the numerous organizational and surgical difficulties encountered. It underscores the importance of surgeons' having been trained in damage control techniques and of being $100 \%$ ready, if need be. Given the 
low number of situations requiring these procedures in current practice, it is essential to include hands-on, actionable learning in initial as well as continuous training. The recent reform in surgery internship teaching in France is a step in the right direction insofar as it carves out a genuine role for practical instruction outside the operating theater (theoretical simulation, animal model and anatomical specimen) and accords priority to emergency training during the key phases of internship. As regards less recently created programs, practical training remains open to French-speaking surgeons, particularly in the framework of an advanced degree (DIU) in visceral traumatology and the military training course known as Cachirmex (Cours Avancé de CHIRurgie en Mission Extérieure).

Practices have likewise been evolving. In closed traumas, as illustrated in the two articles on liver trauma ( $\operatorname{Dr}$ Louise Barbier et al. ${ }^{2}$ ) and diaphragm trauma ( $\operatorname{Dr}$ A. Mancini et al. ${ }^{3}$ ), treatment optimization is multidisciplinary. Close cooperation between the teams involved is necessary in view of correctly establishing an indication for radiological embolization for liver trauma, of providing early diagnosis of biliary complications, and of screening for diaphragmatic ruptures by attentive reading of a scanner or by the rereading of a senior specialist. Difficulties in communication are a major source of at times avoidable mortality, as demonstrated in the article by E. Girard et al. ${ }^{4}$ Non-application of medical care standards is another source of avoidable mortality. Difficulties occur not only in low-volume hospital centers, but also in large-scale university hospitals, whose surgeons (except for emergency surgery !) are often hyper-specialized. Even if there exists no French model for emergency surgery, some simple avenues for improvement merit consideration. French-language recommendations on trauma should be drawn up by our learned societies so that quality care can be provided on the shortest notice, whoever the practitioner on call may be. A referring person in traumatology could also be designated in each structure; he or she would 
be tasked with writing out and updating care protocols (diagnosis, treatment and monitoring) in adequacy with the available means and accessible to all concerned parties. He or she would also be required to coordinate review of morbi-mortality in traumatology, which would represent an obvious source of improvement in daily practice.

Last but not least, the main evolutions in traumatology have been organizational. In numerous developed countries, traumatology organization has been rationalized through the elaboration of networks and registers. A network is a structured organization aimed at ensuring that the care pathway of a trauma patient remain in accordance with quality criteria. The associated registers collect information on patients' lesions and outcomes, thereby facilitating assessment of care effectiveness. Even though the efficacy of this type of organization has been amply demonstrated, France has been lagging; as of now, there does not exist a network or registry on a nationwide scale. That much said, initiatives on a regionwide scale have been either taken or assisted by regional health authorities (ARS). The most adequately structured of these initiatives, developed in the Grenoble area, is known as TRENAU ("Trauma system du REseau Nord Alpin des Urgences"); it brings together systematized organization and a register. As for the register, it is an effective tool favoring and furthering clinical research, as is aptly illustrated in the articles by A. Mancini and E. Girard. Emergency physicians, intensivists and surgeons have recently shown pronounced determination to set up a nationwide care network and register for trauma patients. The foundations for this type of organization have been clearly drawn up ${ }^{5}$. A robust commitment of the surgery community in view of promoting a network and a nationwide trauma patient register will not only accelerate their elaboration, but also enable us to play a key role in development of their architecture. 
Références :

1) D. Massalou, C. Ichai, D. Mariage, P. Baqué. Attaque terroriste à Nice - l'expérience des chirurgiens généraux. JCHIR-17-233R1

2) LA. Barbier, M. Calmels, M. Lagadec, P. Abback, F. Cauchy, M. Ronot, O. Soubrane, C. Paugam-Burtz. Peut-on améliorer la prise en charge des traumatismes hépatiques fermés ? JCHIR-17-237R1

3) A. Mancini, A. Duramé, S. Barbois, J. Abba, F. Ageron, C. Arvieux. Intérêt du diagnostic scannographique précoce dans les ruptures post traumatismes fermés du diaphragme : analyse rétrospective de l'expérience du Trauma System du réseau nord-alpin des urgences. JCHIR$18-43 R 3$

4) E.Girard, Q. Jegousso, B.Boussat, P. Francois, F. Ageron, C. Letoublon, P. Bouzat. Les décès évitables dans un Trauma system régional : analyse sur 6 ans de la mortalité chez les patients traumatisés sévères. JCHIR-18-15R1

5) Gauss T, Balandraud P, Frandon J, Abba J, Ageron FX, Albaladejo P, Arvieux C, et Al. Groupe d'intérêt en traumatologie grave (GITE). Strategic proposal for a national trauma system in France. Anaesth Crit Care Pain Med. 2018 May 29. 